\title{
INCIDENCE, ETIOLOGY AND OUTCOME OF VENTILATOR-ASSOCIATED PNEUMONIA IN PATIENTS WITH PERCUTANEOUS TRACHEOTOMY
}

\author{
Tihana Magdić Turković ${ }^{1}$, Melanija Obraz ${ }^{1}$, Milana Zlatić Glogoški ${ }^{1}$, Ida Juranić ${ }^{2}$ \\ Bruna Bodulica ${ }^{1}$ and Josipa Kovačić ${ }^{1}$
}

${ }^{1}$ Department of Anesthesiology and Intensive Care, Sestre milosrdnice University Hospital Center;

${ }^{2}$ Opus Medicus Occupational Health and Sports Medicine, Zagreb, Croatia

\begin{abstract}
SUMMARY - Although the incidence of ventilator-associated pneumonia (VAP) is very high, there are still many uncertainties about clinical course of VAP among tracheotomized patients. The goal of the present study was to determine the impact of tracheotomy on VAP incidence and etiology, as well as outcome of VAP patients with tracheotomy. The study was conducted in a 15-bed Surgical and Neurosurgical Intensive Care Unit (ICU), Sestre milosrdnice University Hospital Center in Zagreb, Croatia. The study included all patients undergoing only percutaneous tracheotomy during the study period. According to our data, the incidence of VAP among percutaneous tracheotomized patients was $42 \%$, not considering the time between tracheotomy and VAP onset. However, when only patients developing VAP after tracheotomy were taken into account, the incidence of VAP among tracheotomized patients dropped to $8 \%$ only. The most commonly isolated bacterium was Staphylococcus aureus, accounting for 17 (37\%) isolates, followed by Haemophilus influenzae, accounting for another $10(22 \%)$ isolates. The development of VAP among percutaneously tracheotomized patients was associated with longer total ICU stay (regardless of whether VAP developed before or after tracheotomy), while total duration of mechanical ventilation and mortality rate remained unaffected.
\end{abstract}

Key words: Pneumonia, ventilator-associated; Incidence; Tracheotomy - methods

\section{Introduction}

Ventilator associated pneumonia (VAP) is one of the most common infections among Intensive Care Unit (ICU) patients ${ }^{1}$. Although the incidence of VAP is very high, there are still many uncertainties about VAP, inter alia the clinical course of VAP in tracheotomized patients. According to previous studies, the incidence of VAP among tracheotomized patients varies from $6 \%$ to $26 \%{ }^{2,3}$. However, many studies failed to specify the time elapsed between tracheotomy and VAP onset. Only a small number of studies explicitly

Correspondence to: Tihana Magdic Turkovic, MD, Department of Anesthesiology and Intensive Care, Sestre milosrdnice University Hospital Center, Vinogradska c. 29, HR-10000 Zagreb, Croatia E-mail: tihana.magdic.turkovic@gmail.com

Received November 9, 2015, accepted December 19, 2016 state whether tracheotomy preceded VAP or followed it $^{4-9}$.

The goal of the present study was to determine the impact of percutaneous tracheotomy on VAP incidence and etiology, as well as outcome of VAP patients with percutaneous tracheotomy.

\section{Patients and Methods}

The study was conducted in a 15-bed Surgical and Neurosurgical ICU, Department of Anesthesiology and Intensive Care, Sestre milosrdnice University Hospital Center, Zagreb, Croatia. The study was approved by the Hospital Board of Ethics (E.P. number: 35-1/09). Retrospective data were collected from September 2009 to March 2013. Because of the retrospective and observational nature of the study, an informed consent was unnecessary. 
The study included all patients undergoing only percutaneous tracheotomy during the study period. Table 1 shows patient characteristics established at ICU admission. Study patients were divided into two groups according to development of VAP. Those with the diagnosis of VAP were further divided into two subgroups of patients tracheotomized after VAP and those tracheotomized before acquiring VAP; so final analysis included three groups of patients, i.e. VAP before tracheotomy, VAP after tracheotomy, and no VAP.

The reasons for ICU admission were medical, trauma without surgery or postoperative care. The reasons for mechanical ventilation and tracheotomy are shown in Table 2.

Ventilator-associated pneumonia is defined as a type of nosocomial pneumonia occurring more than 48 hours after intubation and mechanical ventilation $(\mathrm{MV})^{10}$. As for the clinical diagnosis, VAP was established according to the Clinical Pulmonary Infection Score (CPIS), based on six clinical assessments, each worth zero to two points ${ }^{11}$. A score of more than six was considered suggestive of VAP. The CPIS score was calculated when there was clinical suspicion of VAP (presence of new or progressive infiltration on chest radiography and presence of at least two of the following criteria: fever, leukocytosis and purulent tracheal secretion). Only the first VAP episode was evaluated. Quantitative culture of endotracheal aspirate (ETA) was performed to identify VAP pathogens. A pathogen isolated in a concentration of more than 10E5 $\mathrm{CFU} / \mathrm{mL}$ was considered causative of VAP. The ETA sample with more than 10 squamous epithelial cells per visual field was considered as invalid sample ${ }^{12}$.

Early-onset VAP was defined as that occurring within the first 4 days of MV and late-onset VAP as that occurring after fourth day of MV.

Percutaneous tracheotomy was performed by ICU physicians at patient bedside using Griggs method. The reasons for performing tracheotomy are shown in Table 2. Tracheotomized patients were divided into those tracheotomized during the first 7 days following ICU admission (early tracheotomy) and those tracheotomized 7 or more days after ICU admission (late tracheotomy).

The exclusion criteria were pneumonia prior to MV or within 48 hours following MV initiation, tracheotomy performed before ICU admission, emergency tracheotomy and age below 18 .
All patients were fed enterally using a nasogastric tube (in most patients starting from the second day of ICU stay), received systematic stress ulcer prophylaxis (ranitidine or proton pump inhibitors) and were kept in a semi-recumbent position during their ICU stay.

Between group comparison was made based on patient status at ICU admission, during ICU stay and at ICU discharge, as well as on the etiology of VAP and characteristics of surviving patients.

\section{Statistical analysis}

Data on patient age, APACHE II score, SAPS II and number of reintubations, as well as number of days on MV or number of days of stay in ICU were expressed as median and $25^{\text {th }}-75^{\text {th }}$ interquartile range, while other data were expressed as number (\%). Continuous variables were compared using Kruskal-Wallis ANOVA, while categorical variables were compared using $\chi^{2}$-test. The values of $\mathrm{p}<0.05$ were considered statistically significant. All statistical analyses were performed using the MedCalc 9.5.1.0 software (MedCalc Software, Mariakerke, Belgium).

\section{Results}

During the study period, 5071 adult patients were admitted to our ICU and 142 (2.8\%) of them underwent percutaneous tracheotomy. Table 1 shows patient characteristics established at ICU admission. Patient groups did not differ significantly according to age, gender, APACHE II score and SAPS II, smoking habit and prevalence of the majority of comorbidities, with the exception of diabetes mellitus. Diabetes mellitus was most prevalent in the VAP after $\mathrm{T}$ group as compared to the two other groups. The proportions of the main reasons for ICU admission were not different among the groups. The type of surgical patients did not significantly differ among the groups. In all groups, postoperative care was the most frequent reason for ICU admission (Table 1).

Ventilator-associated pneumonia developed in 60 (42\%) percutaneously tracheotomized patients, of which 48 (80\%) not tracheotomized before VAP onset (VAP before T) and 12 (20\%) tracheotomized before VAP onset (VAP after T). Eighty-two (58\%) percutaneously tracheotomized patients did not develop VAP during the study period (no VAP). 
Table 1. Patient characteristics at ICU admission

\begin{tabular}{|c|c|c|c|c|}
\hline & VAP before $\mathrm{T}$ & VAP after $\mathrm{T}$ & No VAP & $\mathrm{p}$ value \\
\hline Number of patients & 48 & 12 & 82 & \\
\hline Age (years) & $63(49-74)$ & $64(57-72)$ & $66(49-76)$ & 0.921 \\
\hline \multicolumn{5}{|l|}{ Gender } \\
\hline Male & $36(75)$ & $7(58)$ & $55(67)$ & \multirow{2}{*}{0.452} \\
\hline Female & $12(25)$ & $5(42)$ & $27(33)$ & \\
\hline APACHE II score & $15(11-18)$ & $16(10-20)$ & $16(12-19)$ & 0.761 \\
\hline SAPS II & $40(27-51)$ & $39(35-52)$ & $45(32-55)$ & 0.460 \\
\hline \multicolumn{5}{|l|}{ Main reason for ICU admission } \\
\hline Medical ${ }^{*}$ & $1(2)$ & 0 & $6(7)$ & \multirow{3}{*}{0.173} \\
\hline Trauma without surgery & $4(8)$ & 0 & $13(16)$ & \\
\hline Surgery & $43(90)$ & $12(100)$ & $63(77)$ & \\
\hline \multicolumn{5}{|l|}{ Type of surgical patients } \\
\hline General surgical $^{\dagger}$ & $13(28)$ & $2(17)$ & $13(17)$ & \multirow{2}{*}{0.349} \\
\hline Neurosurgical & $34(72)$ & $10(82)$ & $63(82)$ & \\
\hline \multicolumn{5}{|l|}{ Comorbidity } \\
\hline Diabetes mellitus & $5(10)$ & $5(42)$ & $8(10)$ & 0.007 \\
\hline Malignant disease & $4(8)$ & 0 & $5(61)$ & 0.565 \\
\hline COPD & $3(6)$ & $1(8)$ & $8(10)$ & 0.786 \\
\hline Chronic cardiac disease & $9(19)$ & $2(16)$ & $16(20)$ & 0.971 \\
\hline Kidney failure & $2(4)$ & $2(16)$ & $4(5)$ & 0.219 \\
\hline Alcoholism & $9(19)$ & $2(16)$ & $14(17)$ & 0.967 \\
\hline Smoking & $10(21)$ & $2(16)$ & $18(22)$ & 0.914 \\
\hline Emergency surgery & $41(85)$ & $12(100)$ & $74(90)$ & 0.320 \\
\hline
\end{tabular}

Results are expressed as median $\left(25^{\text {th }}-75^{\text {th }}\right.$ interquartile range) or as number (\%); ICU = intensive care unit; VAP = ventilator-associated pneumonia; $\mathrm{T}=$ (percutaneous) tracheotomy; SAPS II = Simplified Acute Physiology Score II; APACHE II = Acute Physiology and Chronic Health Evaluation II; COPD = chronic obstructive pulmonary disease; "acute respiratory failure, sepsis, state after resuscitation; ${ }^{\dagger}$ neck, thorax, abdomen

Table 2 shows the characteristics of VAP patients observed during ICU stay. The main reason for mechanical ventilation was mostly of respiratory nature in the VAP before $\mathrm{T}$ group, the need for sedation and respiratory reasons at a similar rate in the VAP after $\mathrm{T}$ group, and all three reasons for MV equally represented in the no VAP group. Patient groups did not differ significantly according to the number of reintubations, number of patients treated by antibiotics, glucocorticosteroids, sedatives, dialysis or transfusions, reasons for tracheotomy, timing of tracheotomy and number of days on MV before tracheotomy. The number of days at ICU before tracheotomy was highest in the VAP before $\mathrm{T}$ group as compared to the other two groups. The length of ICU stay before VAP develop- ment and duration of MV before VAP were longer in the VAP after $\mathrm{T}$ group as compared to the VAP before $\mathrm{T}$ group.

Fourteen patients were excluded from the analysis of etiology (invalid sample in four, bacterial growth below $10^{5} \mathrm{CFU} / \mathrm{mL}$ in five, sterile ETA sample in three, and uncollected ETA sample in two patients). So, final analysis of bacterial etiology included $46 \mathrm{pa}-$ tients/ETA samples with 73 bacterial species isolated.

Among 73 isolated bacteria, 52 (71.2\%) were gramnegative bacteria (Table 3). Haemophilus influenzae was the most commonly isolated gram-negative bacterium, accounting for 10 (22\%) isolates. The next most commonly isolated gram-negative bacteria were Pseudomonas aeruginosa and Escherichia coli, each accounting for 
Table 2. Patient characteristics during ICU stay

\begin{tabular}{|c|c|c|c|c|}
\hline & VAP before $T$ & VAP after $\mathrm{T}$ & No VAP & $\mathrm{p}$ value \\
\hline Number of patients & 48 & 12 & 82 & \\
\hline \multicolumn{5}{|l|}{ Reason for MV } \\
\hline Respiratory* & $26(54)$ & $5(42)$ & $24(29)$ & \multirow{3}{*}{0.028} \\
\hline Neurological $^{\dagger}$ & $11(23)$ & $1(8)$ & $28(34)$ & \\
\hline Need for sedation & $11(23)$ & $6(50)$ & $30(37)$ & \\
\hline Number of reintubations & $1(0-2)$ & $0(0-1)$ & $0(0-1)$ & 0.104 \\
\hline \multicolumn{5}{|l|}{ Treatment } \\
\hline Antibiotics & $43(90)$ & $11(92)$ & $65(79)$ & 0.226 \\
\hline Glucocorticoids & $14(29)$ & $2(17)$ & $20(24)$ & 0.616 \\
\hline Sedation & $21(44)$ & $9(75)$ & $43(52)$ & 0.166 \\
\hline Dialysis & $2(4)$ & 0 & $3(4)$ & 0.778 \\
\hline Transfusion & $43(90)$ & $11(92)$ & $65(79)$ & 0.382 \\
\hline \multicolumn{5}{|l|}{ Reason for tracheotomy } \\
\hline Respiratory ${ }^{\ddagger}$ & $21(44)$ & $3(25)$ & $20(24)$ & \multirow{2}{*}{0.063} \\
\hline Neurological $^{\S}$ & $27(56)$ & $9(75)$ & $62(76)$ & \\
\hline \multicolumn{5}{|l|}{ Timing of tracheotomy } \\
\hline Early tracheotomy" & $21(44)$ & $6(50)$ & $51(62)$ & \multirow{2}{*}{0.117} \\
\hline Late tracheotomy & $27(56)$ & $6(50)$ & $31(38)$ & \\
\hline \multicolumn{5}{|l|}{ Length of ICU stay (days) } \\
\hline Before VAP & $5(4-9)$ & $11(10-13)$ & - & 0.001 \\
\hline Before $\mathrm{T}$ & $10(6-13)$ & $7(5-10)$ & $6(5-9)$ & 0.008 \\
\hline \multicolumn{5}{|l|}{ Duration of MV (days) } \\
\hline Before VAP & $3(2-5)$ & $8(6-19)$ & . & 0.001 \\
\hline Before $\mathrm{T}$ & $5(4-8)$ & $5(4-7)$ & $5(3-7)$ & 0.236 \\
\hline Surviving patients & $31(65)$ & $9(75)$ & $61(74)$ & 0.467 \\
\hline
\end{tabular}

Results are expressed as median $\left(25^{\text {th }}-75^{\text {th }}\right.$ interquartile range $)$ or as number $(\%)$; VAP $=$ ventilator-associated pneumonia; $\mathrm{T}$ = (percutaneous) tracheotomy; $\mathrm{MV}=$ mechanical ventilation; $\mathrm{ICU}=$ intensive care unit; *acute respiratory failure, neuromuscular weakness, acute respiratory distress syndrome; ${ }^{\dagger}$ Glasgow Coma Scale (GCS) lower than 9; ${ }^{\ddagger}$ predicted long MV due to trauma or disease of the lung ( $>10$ days), weaning difficulties, neuromuscular weakness/need for frequent suctioning (>10-12 times daily); ${ }^{\S} \mathrm{GCS}$ lower than 9 ; \#during first seven days after admission to ICU; ${ }^{* *}$ from day 8 of ICU admission

another 9 (20\%) isolates, followed by Acinetobacter species (17\%) and Enterobacter species (13\%). The overall number of gram-positive bacterial species was 21 (28.8\%). Table 3 shows that Staphylococcus (S.) aureus was the most commonly isolated gram-positive bacterium. Among all S. aureus isolates, 6 (35.2\%) isolates were methicillin resistant $S$. aureus (MRSA). MRSA was isolated in 4 of 13 (30.8\%) S. aureus isolates in the VAP before T group and in 2 of $4(50 \%) S$. aureus isolates in the VAP after $\mathrm{T}$ group ( $\mathrm{p}=0.495)$. Among all bacteria, the most common cause of VAP was $S$. aureus, accounting for 17 (37\%) of total isolated bacteria. In 12
ETA samples, mixed bacterial and fungal species were isolated. There were 9 Candida species and 3 Aspergillus species isolated. There was no statistically significant difference in the etiology between the VAP before $\mathrm{T}$ group and VAP after T group (Table 3).

Monomicrobial infection occurred in 27 of 46 (58.7\%) patients, and polymicrobial infection in 19 (41.3\%) patients, 14 patients of them infected with two pathogens, three with 3 pathogens and two patients with 4 pathogens.

The overall ICU mortality among percutaneous tracheotomy patients was 29\% (41/142). Mortality 
Table 3. Bacterial species isolated from ETA in VAP patients

\begin{tabular}{|c|c|c|c|c|c|}
\hline & & Total & VAP before $\mathrm{T}$ & VAP after $T$ & $p$ value \\
\hline & Number of ETA samples & 46 & 36 & 10 & \\
\hline & Total number of isolated bacteria & 73 & 57 & 16 & \\
\hline & Gram-negative bacteria & 52 & 41 & 11 & \\
\hline & Moraxella catarrbalis & $2(4)$ & $2(6)$ & 0 & 0.451 \\
\hline & Haemophilus influenzae & $10(22)$ & $8(22)$ & $2(20)$ & 0.882 \\
\hline & Pseudomonas aeruginosa & $9(20)$ & $7(19)$ & $2(20)$ & 0.969 \\
\hline & Acinetobacter species & $8(17)$ & $6(17)$ & $2(20)$ & 0.808 \\
\hline 8 & Escherichia coli & $9(20)$ & $6(17)$ & $3(30)$ & 0.352 \\
\hline 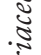 & Klebsiella species & $4(9)$ & $4(11)$ & 0 & 0.275 \\
\hline ड़้ & Enterobacter species & $6(13)$ & $5(14)$ & $1(10)$ & 0.749 \\
\hline 8 & Proteus mirabilis & $1(2)$ & $1(3)$ & 0 & 0.598 \\
\hline 空 & Citrobacter species & $2(4)$ & $2(6)$ & 0 & 0.451 \\
\hline & Unspecified gram-negative bacteria & $1(2)$ & 0 & $1(10)$ & 0.060 \\
\hline & Gram-positive bacteria & 21 & 16 & 5 & \\
\hline & Staphylococcus aureus & $17(37)$ & $13(36)$ & $4(40)$ & 0.823 \\
\hline & Streptococcus pneumoniae & $2(4)$ & $2(6)$ & 0 & 0.451 \\
\hline & ß-hemolytic Streptococcus group B & $1(2)$ & $1(3)$ & 0 & 0.598 \\
\hline & Unspecified gram-positive bacteria & $1(2)$ & 0 & $1(10)$ & 0.060 \\
\hline & Fungi & 12 & 11 & 1 & \\
\hline & Aspergillus & 3 & 3 & 0 & \\
\hline & Candida & 9 & 8 & 1 & \\
\hline
\end{tabular}

Results are expressed as number of bacterial species isolates ( $\%$ of the number of ETA samples); VAP = ventilator-associated pneumonia; ETA = endotracheal aspirate

was not different among the groups (35\% vs. $25 \%$ vs. 26\%, $\mathrm{p}=0.467$ ) (Table 2).

Survival did not differ significantly among patient groups according to any variable observed at ICU admission and during ICU stay, except for the prevalence of diabetes mellitus (Tables 4 and 5). Diabetes mellitus was most prevalent in the VAP after T group as compared to the two other groups.

In surviving patients, total number of days in ICU was shorter in the no VAP group as compared to the other two groups. The length of ICU stay before VAP was shorter in the VAP before $\mathrm{T}$ group as compared to the VAP after $\mathrm{T}$ group. The number of days at ICU before tracheotomy was higher in the VAP before T group as compared to the other two groups. The length of ICU stay after tracheotomy was shorter in the no VAP group as compared to the other two groups. Duration of $\mathrm{MV}$ before VAP was longer in the VAP after $\mathrm{T}$ group as compared to the VAP before T group, and duration of MV after VAP was longer in the VAP before T group as compared to the VAP after T group. Survival did not differ significantly according to the number of ICU days after VAP, total duration of mechanical ventilation, duration of MV before tracheotomy, duration of MV after tracheotomy and SAPS II at discharge (Table 6).

\section{Discussion}

Based on our results, the prevalence of percutaneous tracheotomy in ICU patients was $2.8 \%$. It is a relatively low percentage as compared to the results of other studies ${ }^{8,13-17}$, but the number of percutaneous tracheotomies performed at our ICU has been constantly increasing (from 32 in 2010 to 54 in 2012).

During the study period, the incidence of VAP among percutaneously tracheotomized patients was 
Table 4. Characteristics of surviving patients at ICU admission

\begin{tabular}{|c|c|c|c|c|}
\hline & VAP before $T$ & VAP after $\mathrm{T}$ & No VAP & $p$ value \\
\hline Number of patients & 31 & 9 & 61 & \\
\hline Age (years) & $68(49-81)$ & $60(57-72)$ & $64(48-75)$ & 0.699 \\
\hline \multicolumn{5}{|l|}{ Gender } \\
\hline Male & $23(74)$ & $4(44)$ & $45(74)$ & \multirow{2}{*}{0.176} \\
\hline Female & $8(26)$ & $5(56)$ & $16(26)$ & \\
\hline APACHE II score & $14(10-17)$ & $17(8-20)$ & $16(12-18)$ & 0.626 \\
\hline SAPS II & $33(27-49)$ & $35(31-50)$ & $44(33-52)$ & 0.192 \\
\hline \multicolumn{5}{|l|}{ Main reason for ICU admission } \\
\hline Medical $^{*}$ & $1(3)$ & 0 & $5(8)$ & \multirow{3}{*}{0.310} \\
\hline Trauma without surgery & $3(10)$ & 0 & $11(18)$ & \\
\hline Surgery & $27(87)$ & $9(100)$ & $45(74)$ & \\
\hline \multicolumn{5}{|l|}{ Type of surgical patients } \\
\hline General surgical $^{\dagger}$ & $7(23)$ & $1(11)$ & $5(9)$ & \multirow{2}{*}{0.174} \\
\hline Neurosurgical & $23(77)$ & $8(89)$ & $51(91)$ & \\
\hline \multicolumn{5}{|l|}{ Comorbidity } \\
\hline Diabetes mellitus & $3(10)$ & $4(44)$ & $5(8)$ & 0.007 \\
\hline Malignant disease & $2(6)$ & 0 & 0 & 0.100 \\
\hline COPD & $2(6)$ & 0 & $5(8)$ & 0.659 \\
\hline Chronic cardiac disease & $5(16)$ & $1(11)$ & $10(16)$ & 0.919 \\
\hline Kidney failure & $1(3)$ & $1(11)$ & $2(3)$ & 0.515 \\
\hline Alcoholism & $5(16)$ & $2(22)$ & $12(20)$ & 0.885 \\
\hline Smoking & $5(16)$ & $2(22)$ & $16(26)$ & 0.550 \\
\hline Emergency admission & $26(84)$ & $9(100)$ & $55(90)$ & 0.359 \\
\hline
\end{tabular}

Results are expressed as median $\left(25^{\text {th }}-75^{\text {th }}\right.$ interquartile range $)$ or as number (\%); VAP $=$ ventilator-associated pneumonia; $\mathrm{T}$ = (percutaneous) tracheotomy; SAPS II = Simplified Acute Physiology Score II; APACHE II = Acute Physiology and Chronic Health Evaluation II; COPD = chronic obstructive pulmonary disease; ICU = intensive care unit; 'acute respiratory failure, sepsis, state after resuscitation; ${ }^{\dagger}$ neck, thorax, abdomen

$42 \%$ (60/142). According to recent literature, the incidence of VAP among tracheotomized patients varies from $6 \%$ to $26 \%{ }^{2,3}$, but can be much higher, especially in surgical ICUs ${ }^{18}$. Therefore, the high rate of VAP found in our surgical ICU is in line with these data. Also, prior antibiotic administration is a VAP risk factor too $^{18}$, and almost all our patients were receiving antibiotics. The use of antibiotics may partly explain the higher incidence of VAP recorded in our study. However, many studies have failed to specify the time elapsed from tracheotomy to VAP onset. Only a small number of studies explicitly state whether tracheotomy preceded VAP or followed it ${ }^{4-9}$. To this matter, the work by Nseir et al. even warns that the incidence of VAP after tracheotomy has never been compared with the incidence before tracheotomy or the incidence in patients without tracheotomy ${ }^{4}$. Pawar et al. found that the majority of VAP cases (88.9\%) occur before tracheotomy, so that tracheotomy comes as a result of VAP rather than posing a risk factor for its development ${ }^{6}$. According to our data, the incidence of VAP among tracheotomized patients was $42 \%$, the time elapsed from tracheotomy to VAP onset not being considered. However, when only patients developing VAP after tracheotomy were taken into account, the incidence of VAP among tracheotomized patients dropped to $8 \%(12 / 142)$ only.

To the best of our knowledge, our study was the first to identify diabetes mellitus as a risk factor for VAP-after-T development. Univariate analysis showed 
Table 5. Characteristics of surviving patients during ICU stay

\begin{tabular}{|c|c|c|c|c|}
\hline & VAP before $\mathrm{T}$ & VAP after $\mathrm{T}$ & No VAP & $\mathrm{p}$ value \\
\hline Number of patients & 31 & 9 & 61 & \\
\hline \multicolumn{5}{|l|}{ Reason for MV } \\
\hline Respiratory* & $15(48)$ & $4(44)$ & $14(23)$ & \multirow{3}{*}{0.081} \\
\hline Neurological $^{\dagger}$ & $9(29)$ & $1(12)$ & $23(38)$ & \\
\hline Need for sedation & $7(23)$ & $4(44)$ & $24(39)$ & \\
\hline Number of reintubations & $1(0-2)$ & $0(0-1)$ & $0(0-1)$ & 0.089 \\
\hline \multicolumn{5}{|l|}{ Treatment } \\
\hline Antibiotics & $29(94)$ & $9(100)$ & $50(82)$ & 0.141 \\
\hline Glucocorticoids & $7(23)$ & $1(11)$ & $13(21)$ & 0.747 \\
\hline Sedation & $14(45)$ & $7(78)$ & $33(54)$ & 0.222 \\
\hline Dialysis & 0 & 0 & 0 & - \\
\hline Transfusion & $28(90)$ & $8(89)$ & $48(78)$ & 0.329 \\
\hline \multicolumn{5}{|l|}{ Reason for tracheotomy } \\
\hline Respiratory ${ }^{\ddagger}$ & $12(39)$ & $2(22)$ & $12(20)$ & \multirow{2}{*}{0.138} \\
\hline Neurological ${ }^{\S}$ & $19(61)$ & $7(78)$ & $49(80)$ & \\
\hline \multicolumn{5}{|l|}{ Timing of tracheotomy } \\
\hline Early tracheotomy" & $14(45)$ & $4(44)$ & $37(61)$ & \multirow{2}{*}{0.303} \\
\hline Late tracheotomy & $17(55)$ & $5(56)$ & $24(39)$ & \\
\hline
\end{tabular}

Results are expressed as median $\left(25^{\text {th }}-75^{\text {th }}\right.$ interquartile range) or as number (\%); VAP $=$ ventilator-associated pneumonia; $\mathrm{T}$ = (percutaneous) tracheotomy; $\mathrm{MV}=$ mechanical ventilation; $\mathrm{ICU}$ = intensive care unit; *acute respiratory failure, neuromuscular weakness, acute respiratory distress syndrome; ${ }^{\dagger}$ Glasgow Coma Scale (GCS) lower than 9; ${ }^{*}$ predicted long MV due to trauma or disease of the lung ( $>10$ days), weaning difficulties, neuromuscular weakness/need for frequent suctioning (>10-12 times daily); ${ }^{\S} \mathrm{GCS}$ lower than 9 ; \#during first seven days after admission to ICU; ** from day 8 of ICU admission

diabetes mellitus to be most prevalent in the VAP after $\mathrm{T}$ arm. Whether diabetes mellitus really is a risk factor for VAP development is hard to tell because of the small number of patients in the VAP after $\mathrm{T}$ arm. Some studies found diabetes mellitus to be more common among VAP patients ${ }^{19,20}$, whereas others report that diabetes mellitus does not pose a risk factor for VAP onset ${ }^{21}$.

In the VAP before $\mathrm{T}$ arm, the main reason for starting MV was of respiratory nature, whereas in the VAP after $\mathrm{T}$ arm MV was introduced due to the need of sedation, as well as for respiratory reasons (both grounds for MV initiation, thereby being represented in similar rates). In the no VAP group, all of the above grounds for MV introduction were equally represented. The possible reasons behind the earlier VAP development witnessed in the VAP before $\mathrm{T}$ arm could be respiratory tract-related, whereas VAP seen in the VAP after $T$ arm it could have been the result of prolonged ICU stay and prolonged MV, the latter being known as a risk factor favoring VAP development. Namely, the length of pre-VAP ICU stay and the length of pre-VAP MV were proven to be statistically significantly shorter in the VAP before $\mathrm{T}$ as compared to the VAP after $\mathrm{T}$ arm, both when it comes to all patients under study and the surviving patients only. The afore-mentioned findings lead to a conclusion that VAP seen in the VAP before $\mathrm{T}$ arm could mostly be characterized as an early-developing one. Numerous researches conducted insofar have shown early-emerging VAP to be associated with lower mortality rates, shorter MV duration and shorter ICU stay ${ }^{22}$. However, our data indicated the mortality rates to be equal in the two arms, while MV duration and ICU stay length both turned out to be shorter in the VAP before T, i.e. in the early VAP arm. In surviving patients, post-VAP MV and post-VAP ICU stay were proven to be shorter in the VAP after T, i.e. in the late VAP arm. The most probable reason for the shorter MV and shorter ICU stay seen across the above study arm is the fact 
Table 6. Characteristics of surviving patients at ICU discharge

\begin{tabular}{|l|l|l|l|l|}
\hline & VAP before T & VAP after T & No VAP & p value \\
\hline Number of patients & 31 & 9 & 61 & \\
\hline Length of ICU stay (days) & & & & \\
$\quad$ Total & $19(14-28)$ & $19(16-27)$ & $14(10-23)$ & 0.038 \\
Before VAP & $5(4-9)$ & $11(10-12)$ & - & $<0.001$ \\
After VAP & $13(9-21)$ & $9(6-14)$ & - & 0.173 \\
Before T & $10(6-13)$ & $7(5-10)$ & $6(5-9)$ & 0.022 \\
After T & $10(6-16)$ & $11(9-20)$ & $7(3-15)$ & 0.048 \\
\hline Duration of MV (days) & & & & \\
Total & $8(5-17)$ & $7(6-11)$ & $7(5-11)$ & 0.698 \\
Before VAP & $3(2-6)$ & $7(5-9)$ & - & 0.004 \\
After VAP & $4(2-10)$ & $1(0-1)$ & - & 0.008 \\
Before T & $5(4-8)$ & $5(4-7)$ & $5(3-7)$ & 0.555 \\
After T & $1(0-6)$ & $1(1-7)$ & $2(1-3)$ & 0.991 \\
\hline SAPS II & $27(19-31)$ & $22(15-24)$ & $28(21-41)$ & 0.082 \\
\hline
\end{tabular}

Results are expressed as median $\left(25^{\text {th }}-75^{\text {th }}\right.$ interquartile range $)$ or as number (\%); VAP $=$ ventilator-associated pneumonia; $\mathrm{T}$ = (percutaneous) tracheotomy; $\mathrm{MV}=$ mechanical ventilation; $\mathrm{ICU}=$ intensive care unit; $\mathrm{SAPS}$ II = Simplified Acute Physiology Score II

that, at the VAP nascence time-point, most of the patients assigned to that study group had already been tracheotomized, thus tracheotomy being a contributor to earlier weaning from MV and subsequently also to shorter ICU stay. The study by Nseir et al. showed lower mortality rates in early VAP-developing patients ${ }^{4}$, but some of the prospective studies failed to confirm the above results ${ }^{23-25}$.

Many studies compared the impact of early versus late tracheotomy in terms of the ability to reduce MV duration and length of ICU stay. According to many prospective randomized studies, early tracheotomy seems to reduce the duration of MV and the length of ICU stay ${ }^{26-29}$. However, a few recent meta-analyses failed to confirm any favorable impact of early tracheotomy on MV duration and length of ICU stay ${ }^{30}$. According to our results, the duration of pre-tracheotomy MV was similar in all study arms. Also, weaning from MV took place at a similar post-tracheotomy time point, suggesting that tracheotomy itself rather than its timing was the critical factor responsible for the duration of post-tracheotomy MV. The length of pretracheotomy ICU stay was proven longer in the VAP before tracheotomy arm as compared to other study arms, so that VAP before tracheotomy patients could be classified as those having late tracheotomy, while members of the other study groups could be classified as those having early tracheotomy. The length of posttracheotomy ICU stay was shorter in the no VAP group as compared to other study arms. These data suggest that early tracheotomy is associated with a reduced length of post-tracheotomy ICU stay, but only in patients that did not develop VAP.

Ventilation-associated pneumonia is associated with high mortality rates. According to our data, mortality rates recorded in our study patients did not differ among the study arms (35\% vs. $25 \%$ vs. $25 \%$; $\mathrm{p}=0.467$ ) (Table 2). The all-cause mortality recorded among percutaneously tracheotomized patients was 29\% (41/142). This percentage is similar to the VAP mortality rate reported in the literature ${ }^{3,8}$. Some studies found increased mortality rates in VAP patients ${ }^{5,6,31}$, whereas others failed to demonstrate any impact of VAP on the mortality rate ${ }^{3,32}$. A case-control study that included 85 VAP patients well matched with 85 controls has reported a VAP mortality rate of $40 \%$ and non-VAP mortality rate of $38.8 \%$, that is to say, there was no statistically significant between-group difference $^{32}$. Neither did Rello et al. establish a significantly higher mortality rate among VAP as compared to VAP-free patients ${ }^{3}$. Causal relationship between high VAP mortality and VAP itself has been a subject of 
debate, some thereby perceiving VAP simply as a sign of general downhill course witnessed in seriously ill patients. These observations may indicate that, in critically ill patients, host factors and underlying diseases are more important outcome determinants than either the microorganisms responsible for VAP development or the treatments administered. Based on our results, mortality rate seen in the VAP before $\mathrm{T}$ arm was higher than that observed in the VAP after T and no VAP arms (35\% vs. 25\%), although the difference was not statistically significant. Since shortening of MV duration, tracheotomy may have contributed to faster patient recovery and lower mortality, although the contribution was obviously not statistically significant. In their retrospective study that included more than 9000 patients, Rello et al. found no difference in mortality rates between patients with and without VAP ${ }^{33}$.

Earlier reports pointed to gram-negative bacteria as the most common VAP-causative agent ${ }^{34}$. In our study, 52 (71.2\%) VAP cases were caused by gramnegative bacteria, which is in line with the results of similar studies, in which approximately $60 \%$ of VAPcausing bacteria were found to be gram-negative ${ }^{1}$. However, judging by our data, the most commonly isolated species was the gram-positive bacterium strain Staphylococcus aureus, accounting for 36\% of VAP before $\mathrm{T}$ and $40 \%$ of VAP after T cases. According to Park et al., one of the risk factors for the development of VAP caused by Staphylococcus aureus is a neurosurgical procedure justifying ICU admission ${ }^{35}$, and our study arm constituted of percutaneously tracheotomized patients included 107 (75\%) neurosurgical patients. The etiologic backgrounds were similar across the study arms, their similarity thereby being a possible reason for the similarity of mortality rates recorded in each study $\operatorname{arm}^{1}$.

In $30 \%-50 \%$ of cases, VAP has been reported to be a polymicrobial infection, the reported rates thereby differing based on the diagnostic method used ${ }^{1}$. In our patients, polymicrobial VAP genesis was confirmed in $41.3 \%$ of cases.

Total MV duration has often been tagged as a risk factor facilitating VAP development ${ }^{1}$; nevertheless, it should not be perceived as such, although it is truly longer in VAP patients, just because of the VAP itself, i.e development of VAP is the cause of prolonged MV. Only the occurrence precedent to VAP, and not one emerging post VAP, can be perceived as a VAP risk factor, so that only the duration of pre-VAP MV rather than total MV duration should be seen as a VAP risk factor. On top of that, post-VAP MV duration should be analyzed solely in surviving patients, since the only reason for shorter MV duration in some of eventually departed patients is the fatal outcome itself. Based on our data, total MV duration recorded across the surviving VAP and VAP-free patients does not differ at all.

We also found that patients having developed VAP stayed longer at ICU than those free from VAP. Similar results concerning the relevance of ICU stay length for VAP patients have also been reported elsewhere ${ }^{6}$. Our results also suggest the length of ICU stay among percutaneously tracheotomized VAP patients to be similar regardless of whether VAP developed before or after tracheotomy.

In conclusion, the development of VAP among percutaneously tracheotomized patients was associated with longer total ICU stay (regardless of whether VAP developed before or after tracheotomy), while total duration of MV and mortality rate remained unaffected.

Our study had some limitations in terms of retrospective and observational nature, heterogeneity of reasons for ICU admission, single ICU coverage and small sample size, especially when it comes to the VAP after $\mathrm{T}$ arm.

\section{References}

1. Chastre J, Fagon JY. Ventilator-associated pneumonia. Am J Respir Crit Care Med. 2002;165(7):867-903. DOI: 10.1164/ ajrccm.165.7.2105078

2. Georges H, Leroy O, Guery B, Alfandari S, Beaucaire G. Predisposing factors for nosocomial pneumonia in patients receiving mechanical ventilation and requiring tracheotomy. Chest. 2000;118(3):767-74.

3. Rello J, Lorente C, Diaz E, Bodi M, Boque C, Sandiumenge A, et al. Incidence, etiology, and outcome of nosocomial pneumonia in ICU patients requiring percutaneous tracheotomy for mechanical ventilation. Chest. 2003;124(6):2239-43.

4. Nseir S, Di Pompeo C, Jozefowicz E, Cavestri B, Brisson H, Nyunga $M$, et al. Relationship between tracheotomy and ventilator-associated pneumonia: a case control study. Eur Respir J. 2007;30(2):314-20. DOI: 10.1183/09031936.06.00024906

5. Ibrahim EH, Tracy L, Hill C, Fraser VJ, Kollef MH. The occurrence of ventilator-associated pneumonia in a community hospital: risk factors and clinical outcomes. Chest. 2001;120 (2):555-61. 
6. Pawar M, Mehta Y, Khurana P, Chaudhary A, Kulkarni V, Trehan N. Ventilator-associated pneumonia: incidence, risk factors, outcome, and microbiology. J Cardiothorac Vasc Anesth. 2003;17(1):22-8. DOI: 10.1053/jcan.2003.4

7. Blot F, Guiguet M, Antoun S, Leclercq B, Nitenberg G, Escudier B. Early tracheotomy in neutropenic, mechanically ventilated patients: rationale and results of a pilot study. Support Care Cancer. 1995;3(5):291-6.

8. Clec'h C, Alberti C, Vincent F, Garrouste-Orgeas M, de Lassence A, Toledano D, et al. Tracheostomy does not improve the outcome of patients requiring prolonged mechanical ventilation: a propensity analysis. Crit Care Med. 2007;35(1):132-8. DOI: 10.1097/01.CCM.0000251134.96055.A6

9. Ranes JL, Gordon SM, Chen P, Fatica C, Hammel J, Gonzales JP, et al. Predictors of long-term mortality in patients with ventilator-associated pneumonia. Am J Med. 2006;119(10): e13-9. DOI: 10.1016/j.amjmed.2005.12.034

10. Hunter JD. Ventilator associated pneumonia. Postgrad Med J. 2006;82(965):172-8. DOI: 10.1136/pgmj.2005.036905

11. Pugin J, Auckenthaler R, Mili N, Janssens JP, Lew PD, Suter PM. Diagnosis of ventilator-associated pneumonia by bacteriologic analysis of bronchoscopic and nonbronchoscopic "blind" bronchoalveolar lavage fluid. Am Rev Respir Dis. 1991;143(5 Pt 1):1121-9.

12. Morris AJ, Taner DC, Reler LB. Rejection criteria for endotracheal aspirates from adults. J Clin Microbiol. 1993;31(5): 1027-9.

13. Frutos-Vivar F, Esteban A, Apezteguía C, Anzueto A, Nightingale $\mathrm{P}$, Gonzalez M, et al. International Mechanical Ventilation Study Group Outcome of mechanically ventilated patients who require a tracheostomy. Crit Care Med. 2005;33(2):290-8.

14. Flaatten H, Gjerde S, Heimdal JH, Aardal S. The effect of tracheostomy on outcome in intensive care unit patients. Acta Anaesthesiol Scand. 2006;50(1):92-8. DOI: 10.1111/j.1399$-6576.2005 .00898 . x$

15. Beltrame F, Zussino M, Martinez B, Dibartolomeo S, Saltarini $\mathrm{M}$, Vertrugno L, et al. Percutaneous versus surgical bedside tracheostomy in the intensive care unit: a cohort study. Minerva Anestesiol. 2008;74(10):529-35.

16. Jeon YT, Hwang JW, Lim YJ, Lee SY, Woo KI, Park HP. Effect of tracheostomy timing on clinical outcome in neurosurgical patients: early versus late tracheostomy. J Neurosurg Anesthesiol.2014;26(1):22-6.DOI: 10.1097/ANA.0b013e31829770a0

17. Chaari A, Kssibi H, Zribi W, Medhioub F, Chelly H, Algia $\mathrm{NB}$, et al. Ventilator-associated pneumonia in trauma patients with open tracheotomy: predictive factors and prognosis impact. J Emerg Trauma Shock. 2013;6(4):246-51.

18. Kollef MH. Ventilator-associated pneumonia. A multivariate analysis. JAMA. 1993;270(16):1965-70.

19. Miki Y, Makuuchi R, Tokunaga M, Tanizawa Y, Bando E, Kawamura T, et al. Risk factors for postoperative pneumonia after gastrectomy for gastric cancer. Surg Today. 2016;46(5): 552-6. DOI: $10.1007 / \mathrm{s} 00595-015-1201-8$
20. Hachenberg T, Sentürk M, Jannasch O, Lippert H. Postoperative wound infections. Pathophysiology, risk factors and preventive concepts. Anaesthesist. 2010;59(9):851-66, http:// dx.doi.org/10.1007/s00101-010-1789-4

21. Sotirović J, Šuljagić V, Baletić N, Pavićević L, Bijelić D, Erdoglija $\mathrm{M}$, et al. Risk factors for surgical site infection in laryngeal cancer surgery. Acta Clin Croat. 2015r;54(1):57-64.

22. American Thoracic Society; Infectious Diseases Society of America. Guidelines for the management of adults with hospital-acquired, ventilator-associated, and healthcare-associated pneumonia. Am J Respir Crit Care Med. 2005;171(4): 388-416.

23. Rodriguez JL, Steinberg SM, Luchetti FA, Gibbons KJ, Taheri PA, Flint LM. Early tracheostomy for primary airway management in the surgical critical care setting. Surgery. 1990;108(4): 655-9.

24. Dunham CM, Ransom KJ. Assessment of early tracheostomy in trauma patients: a systematic review and meta-analysis. Am Surg. 2006;72(3):276-81.

25. Sugerman HJ, Wolfe L, Pasquale MD, Rogers FB, O'Malley $\mathrm{KF}$, Knudson M, et al. Multicenter, randomized, prospective trial of early tracheostomy. J Trauma. 1997;43(5):741-7.

26. Terragni PP, Antonelli M, Fumagalli R, Faggiano C, Berardino $\mathrm{M}$, Pallavicini FB, et al. Early vs late tracheotomy for prevention of pneumonia in mechanically ventilated adult ICU patients: a randomized controlled trial. JAMA. 2010;303(15): 1483-9. DOI: $10.1001 /$ jama.2010.447

27. Gandia-Martinez F, Martinez-Gil I, Andaluz-Ojeda D, Bobillo de Lamo F, Parra-Morais L, Diez-Gutierrez F. Analysis of early tracheostomy and its impact on development of pneumonia, use of resources and mortality in neurocritically ill patients. Neurocirugia. 2010;21(3):211-21.

28. Koch T, Hecker B, Hecker A, Brenck F, Preuß M, Schmelzer $\mathrm{T}$, et al. Early tracheostomy decreases ventilation time but has no impact on mortality of intensive care patients: a randomized study. Langenbecks Arch Surg. 2012;397(6):1001-8. DOI: 10.1007/s00423-011-0873-9

29. Zheng Y, Sui F, Chen XK, Zhang GC, Wang XW, Zhao S, et al. Early versus late percutaneous dilational tracheostomy in critically ill patients anticipated requiring prolonged mechanical ventilation. Chin Med J (Engl). 2012;125(11):1925-30.

30. Wang F, Wu YP, Bo LL, Lou JS, Zhu JL, Chen F, et al. The timing of tracheotomy in critically ill patients undergoing mechanical ventilation: a systematic review and meta-analysis of randomized controlled trials. Chest. 2011;140(6):1456-65. DOI: $10.1378 /$ chest.11-2024

31. Gupta A, Agrawal A, Mehrotra S, Singh A, Malik S, Khanna A. Incidence, risk stratification, antibiogram of pathogens isolated and clinical outcome of ventilator associated pneumonia. Indian J Crit Care Med. 2011;15(2):96-101.

32. Papazian L, Bregeon F, Thirion X, Gregoire R, Saux P, Denis $\mathrm{JP}$, et al. Effect of ventilator-associated pneumonia on mortality and morbidity. Am J Respir Crit Care Med. 1996;154(1):91-7. DOI: 10.1164/ajrccm.154.1.8680705 
33. Rello J, Ollendorf DA, Oster G, Vera-Llonch M, Bellm L, Redman R, et al. VAP Outcomes Scientific Advisory Group. Epidemiology and outcomes of ventilator-associated pneumonia in a large US database. Chest. 2002;122(6):2115-21.

34. Magdić Turković T, Gverić Grginić A, Đuras Cuculić B, Gašpar B, Širanović M, Perić M. Microbial profile and anti- biotic susceptibility patterns of pathogens causing ventilatorassociated pneumonia at Intensive Care Unit, Sestre milosrdnice University Hospital Center, Zagreb, Croatia. Acta Clin Croat. 2015;54(2):127-35.

35. Park DR. The microbiology of ventilator-associated pneumonia. Respir Care. 2005;50(6):742-63.

Sažetak

\section{INCIDENCIJA, ETIOLOGIJA I ISHOD PERKUTANO TRAHEOTOMIRANIH BOLESNIKA S VENTILACIJSKOM PNEUMONIJOM}

\section{T. Magdić Turković, M. Obraz, M. Zlatić Glogoški, I. Juranić, B. Bodulica i J. Kovačić}

Iako je učestalost ventilacijske pneumonije (VAP) vrlo visoka, postoje mnoge nedoumice vezane uz klinički tijek VAP-a među traheotomiranim bolesnicima. Cilj ovoga istraživanja bio je utvrditi utjecaj traheotomije na učestalost i etiologiju VAP-a, kao i ishod traheotomiranih bolesnika s VAP-om. Istraživanje je provedeno u 15-krevetnoj kirurškoj i neurokirurškoj Jedinici intenzivnog liječenja Kliničkog bolničkog centra "Sestre milosrdnice" u Zagrebu. Svi i samo perkutano traheotomirani bolesnici tijekom razdoblja istraživanja bili su uključeni u istraživanje. Prema našim podacima, učestalost VAP-a među perkutano traheotomiranim bolesnicima bila je $42 \%$ ako se u obzir ne uzima vrijeme pojave VAP-a u odnosu na vrijeme izvođenja traheotomije. Međutim, ako se u obzir uzmu samo bolesnici u kojih se VAP javio nakon izvođenja traheotomije učestalost VAP-a među traheotomiranim bolesnicima opada na samo 8\%. Najčešće izolirana bakterija je bila Staphylococcus aureus, izolirana u 17 (37\%) izolata, iza koje slijedi Haemophilus influenzae, izolirana u sljedećih 10 (22\%) izolata. Razvoj VAP-a među perkutano traheotomiranim bolesnicima je bio povezan s dužim ostankom u Jedinici intenzivnog liječenja (bez obzira je li se VAP javio prije ili nakon izvođenja traheotomije), dok na ukupno trajanje mehaničke ventilacije i smrtnost nije imao utjecaja.

Ključne riječi: Pneumonija, ventilacijska; Incidencija; Traheotomija - metode 